\title{
ACOUSTIC AND ELECTROMAGNETIC EMISSION OF LIGHTWEIGHT CONCRETE WITH POLYPROPYLENE FIBERS
}

\author{
AKUSTIČNA IN ELEKTROMAGNETNA EMISIJA LAHKEGA \\ BETONA S POLIPROPILENSKIMI VLAKNI
}

\author{
Richard Štoudek ${ }^{1}$, Tomáš Trčka², Michal Matysík ${ }^{1}$, Tomáš Vymazal${ }^{1}$, \\ Iveta Plšková ${ }^{1}$ \\ ${ }^{1}$ Brno University of Technology, Faculty of Civil Engineering, Veveři 331/95, 60200 Brno, Czech Republic \\ ${ }^{2}$ Brno University of Technology, Faculty of Electrical Engineering and Communication, Technická 3058/10, 616 00 Brno, Czech Republic \\ matysik.m@fce.vutbr.cz
}

Prejem rokopisa - received: 2015-06-29; sprejem za objavo - accepted for publication: 2015-07-08

doi: $10.17222 /$ mit. 2015.138

This paper is focused on failure monitoring in lightweight concrete (special high-performance concrete that contains porous aggregate with a low bulk density) with high-strength polypropylene fibers under mechanical loading. The aim was to determine how the cracks' generation intensity in the tested concrete samples depends on the fibers' length and quantity. Our diagnostic method is based on a measurement of the acoustic and electromagnetic emission signals, which occur when solid dielectric materials are mechanically stressed. Several groups of lightweight concrete samples with various types and concentrations of high-strength polypropylene fibers were prepared for our experiment. We made two-channel measurements of the concrete samples from each group for defined loading conditions. The first channel was electromagnetic emission (EME) and the second was acoustic emission (AE). The electromagnetic emission and acoustic emission methods are promising methods to study the generation and behavior of cracks. The main advantage of EME and AE is their ability to be detected already in the stressed stage, which prevents macroscopic deterioration in solids. From the obtained results it can be concluded that the generated cracks' intensity is significantly affected by the presence of polypropylene fibers and by their length and dosage.

Keywords: acoustic emission, electromagnetic emission, lightweight concrete, fibers

Članek je usmerjen na pregled poškodb pri mehanskem obremenjevanju lahkega betona (poseben visoko zmogljiv beton, ki vsebuje porozne sestavine $\mathrm{z}$ majhno gostoto), z visokotrdnostnimi polipropilenskimi vlakni. Namen je bil ugotoviti, kako je intenziteta nastanka razpok odvisna od dolžine in količine vlaken. Diagnostična metoda je temeljila na merjenju akustičnih signalov in signalov elektromagnetne emisije, ki se pojavijo kadar je trden dielektrični material mehansko obremenjen. Za eksperiment je bilo pripravljenih več vrst lahkih betonov z različno vrsto in koncentracijo visokotrdnostnih polipropilenskih vlaken. Pri določenih pogojih obremenitve smo izvršili dvokanalne meritve vzorcev betona iz vsake skupine. Prvi kanal je bila elektromagnetna emisija (EME), drugi pa akustična emisija (AE). Metodi elektromagnetne emisije in akustične emisije sta obetajoči metodi za študij nastanka in obnašanja razpok. Glavna prednost EME in AE je, da ju je mogoče odkriti že med stanjem napetosti, kar prepreči lokalne makroskopske poškodbe v trdnem stanju. Iz dobljenih rezultatov je mogoče zaključiti, da je intenzivnost nastajanja razpoke močno odvisna od prisotnosti polipropilenskih vlaken, od njihove dolžine in odmerka.

Ključne besede: akustična emisija, elektromagnetna emisija, lahki beton, vlakna

\section{INTRODUCTION}

Cracks very often generate in the structures of both normal and lightweight concrete. They can interfere only with the surface of the concrete body, or penetrate the whole volume. In both cases these cracks have a highly negative affect, not only on the static and deformation characteristics of the concrete, and thus the static behavior of the structure as a whole, but also lead to an intensive reduction of the durability. The source of these cracks can be the volume changes of the concrete (plastic shrinkage and settlement, heat of hydration, autogenous shrinkage, drying) or by external strain (cracks from bending and shearing stress). ${ }^{1}$

When a solid is exposed to mechanical stress, emission of electrons, ions, ground-state and excited neutrals, free radicals, electromagnetic emission in the frequency range from tenths of $\mathrm{Hz}$ up to gamma radiation and acoustic emission may take place under certain condi- tions. This phenomenon is generally termed fracto-emission. Fracto-emission may be due to several kinds of mechanical stress: tensile, compression, and torsional stress. Furthermore, it may be induced by friction, shock, drilling, splitting, scaling, grinding, skimming etc. ${ }^{2,3}$ This phenomenon is particularly strong in composite materials. In the frequency domain these processes are characterized as a flicker noise, especially in the low-frequency range. Several authors put forward a physical interpretation directly connected with particular non-homogeneous structures. ${ }^{4}$

Electromagnetic emissions in the radio-frequency region (EME) make up one of very important fractoemission components for material research in physics as well as in engineering. In the past, great attention was paid to the application of EME from rocks and minerals being exposed to a mechanical stress, both in connection with earthquake and volcanic activity predictions and in rock mechanics. ${ }^{5-7}$ Although there are a number of 
experimental papers dealing with various aspects of EME, the physical origin of this phenomenon is not sufficiently known for the time being.

Our diagnostic method designed for experimental examinations of EME signals in composite materials is based on an experimental fact, namely, that the formation of cracks in an electrically non-conducting material is accompanied by the generation of an electromagnetic field. ${ }^{8}$ The cracks' generation in solids is accompanied by the redistribution of the electric charge. The crack walls are electrically charged and their vibrations produce time-variable electrical dipole moments. Hence, the individual cracks become electromagnetic field sources, which can be measured with the appropriate sensors. ${ }^{8}$

The signal of the acoustic emission (AE) is generated simultaneously with the EME signal. Acoustic emission appears due to the release of elastic energy during this process and it is in the frequency range of ultrasonic waves. ${ }^{9}$

The electromagnetic emission and acoustic emission methods are promising methods for studying the generation and behavior of cracks. The main advantage of EME and AE is their ability to be detected already in the stressed stage, which prevents the macroscopic deterioration in solids. A suitably designed methodology of EME and AE signals measurement, processing and evaluation allows us to observe the response of stressed materials to an applied mechanical load continuously and also allows us to obtain useful information about the processes taking place in the cracks' formation in solids. ${ }^{10-12}$ For the time being, the EME method is the only method suitable for studying the time development of crack growth (crack-propagation speed, crack-face movement speed, crack length and size, etc.). ${ }^{13,14}$

\section{EXPERIMENTAL PART}

For EME and AE observations the automatic measurement system was developed. It is schematically shown in Figure 1. The adjustable hydraulic press is controlled by computer via a voltage that is set by card NI PCI-6014. A press provides a mechanical load in the range from $10 \mathrm{kN}$ up to $110 \mathrm{kN}$. The measurement card acquires the output voltage of the Wheatstone bridge with a sensitive load cell that measures the mechanical load. A deformation meter is used to measure the sample's contraction during a compressive stress application. The data from the deformation meter are read and processed by computer.

For the EME detection we used capacitance sensors. Our capacitance sensor was formed by a specially made adjustable bracket with two electrodes, into which we can easily insert the rectangular samples from the studied material.

For AE capturing the piezoelectric sensors were used. These sensors meet the requirements of the AE frequency band (at least up to $1 \mathrm{MHz}$ ). Beeswax was applied for good mechanical coupling between the sensors and the specimen.

The EME measurement channel consists of a capacitance sensor, the dielectric of which is composed of the stressed sample, a high-pass-filter-type load impedance ZL, a low-noise preamplifier PA31, and an amplifier AM22 with a set of filters. The total EME channel gain is $60 \mathrm{~dB}$, the frequency range is from $30 \mathrm{kHz}$ to $1.2 \mathrm{MHz}$ and the sampling rate is $5 \mathrm{MHz}$.

The AE channel consists of a piezoelectric acoustic sensor $(30 \mathrm{kHz} \sim 1 \mathrm{MHz})$, the low-noise preamplifier PA31 and the amplifier AM22 with a set of filters. The total AE channel gain is $40 \mathrm{~dB}$, while the frequency range is from $30 \mathrm{kHz}$ to $1.2 \mathrm{MHz}$.

EME and AE Preamplifiers and Amplifiers:

- Preamplifier (3S SEDLAK PA31): This low-noise preamplifier exhibits a bandwidth from $20 \mathrm{~Hz}$ to 10 $\mathrm{MHz}$, a high input impedance $10 \mathrm{M} \Omega / 20 \mathrm{pF}$, a variable gain of $6 / 20 / 40 \mathrm{~dB}$ and a noise voltage $<1.8$ $\mathrm{nV} / \mathrm{vHz}$.

- Amplifier (3S SEDLAK AM22): This low-noise amplifier exhibits a bandwidth from $0.3 \mathrm{~Hz}$ to $1.2 \mathrm{MHz}$, a set of high-pass and low-pass filers, an input impedance of $1 \mathrm{M} \Omega / 50 \mathrm{pF}$ and a noise voltage $<3$ $\mathrm{nV} / \mathrm{vHz}$.

Both signals of the EME and AE are acquired by the NI PCI 6111 card and stored in the PC. The stored data is processed using our software. The whole measurement system is controlled by a computer with the software developed in LabVIEW. The software makes it possible to find the typical events in the EME and AE. The evaluation process for these parameters and the measurement process are provided in real time and simultaneously.

Our study is focused on lightweight concrete with polypropylene fibers. Classical lightweight concrete (without polypropylene fibers) has been used as a reference sample. This fresh concrete mixture was prepared from Liapor 4-8/600 lightweight aggregates (LWA), heavyweight aggregates (HWA) of a 0-4-mm fraction, CEM I - 42.5 R cement, fly ash, plasticizer and water. The water and lightweight aggregates of a 4-8-mm fraction were dosed by volume, the remaining components

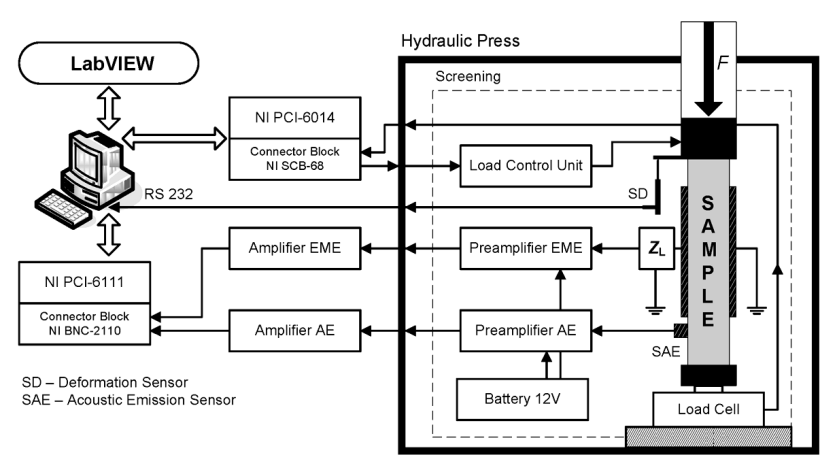

Figure 1: Experimental set-up

Slika 1: Eksperimentalni sestav 


\section{R. ŠTOUDEK et al.: ACOUSTIC AND ELECTROMAGNETIC EMISSION OF LIGHTWEIGHT CONCRETE ...}

by weight. The composition of the fresh concrete mixture is in Table 1.

Table 1: Composition of fresh concrete mixture (reference sample) Tabela 1: Sestava sveže mešanice betona (referenčni vzorec)

\begin{tabular}{|l|c|c|}
\hline \multicolumn{1}{|c|}{ Components } & Units & $\begin{array}{c}\text { Quantities } \\
\text { per 1 } \mathrm{m}^{3}\end{array}$ \\
\hline LWA Liapor 4-8/600 & $\mathrm{L}$ & 440 \\
\hline HWA 0-4 mm Bratčice & $\mathrm{kg}$ & 580 \\
\hline Cement 42.5 R & $\mathrm{kg}$ & 400 \\
\hline Fly ash Trinec & $\mathrm{kg}$ & 50.0 \\
\hline Plasticizer Sika Viscocrete 1035 & $\mathrm{kg}$ & 5.00 \\
\hline Water & $\mathrm{L}$ & 206 \\
\hline
\end{tabular}

Table 2: Dosage of polypropylene fibers, additional water and plasticizer. The length of the fibers is shown in brackets.

Tabela 2: Odmerek polipropilenskih vlaken, dodatka vode in plastifikatorja. Dolžina vlaken je prikazana v oklepajih.

\begin{tabular}{|c|c|c|c|c|c|c|}
\hline Components & \multicolumn{6}{|c|}{ Quantities per $1 \mathrm{~m}^{3}(\mathrm{~kg})$} \\
\hline Forta Ferro (54 mm) & - & 9.0 & & 6.0 & 4.0 & 2.0 \\
\hline $\begin{array}{c}\text { Forta Econo-Net } \\
(38 \mathrm{~mm})\end{array}$ & - & - & 9.0 & 1.5 & 1.0 & 0.5 \\
\hline $\begin{array}{c}\text { Forta Econo-Net } \\
(19 \mathrm{~mm})\end{array}$ & - & - & - & 1.5 & 1.0 & 0.5 \\
\hline Additional water & - & 60 & 40 & 60 & 20 & - \\
\hline Additional plasticizer & - & - & - & 0.8 & 0.8 & 0.8 \\
\hline $\begin{array}{c}\text { Designation of the } \\
\text { mixture }\end{array}$ & & & & & & \\
\hline
\end{tabular}

We also made five mixtures of fiber-lightweight concrete, which are mutually of a different type and amount of polypropylene fibers. The compositions of these concretes were based on the reference lightweight concrete to the basic components was added an appropriate dose of fibers and the consistency of the mixtures was adjusted by adding water, possibly plasticizer. The dosage of the fibers, additional water and plasticizer, for the individual mixtures is shown in Table 2.

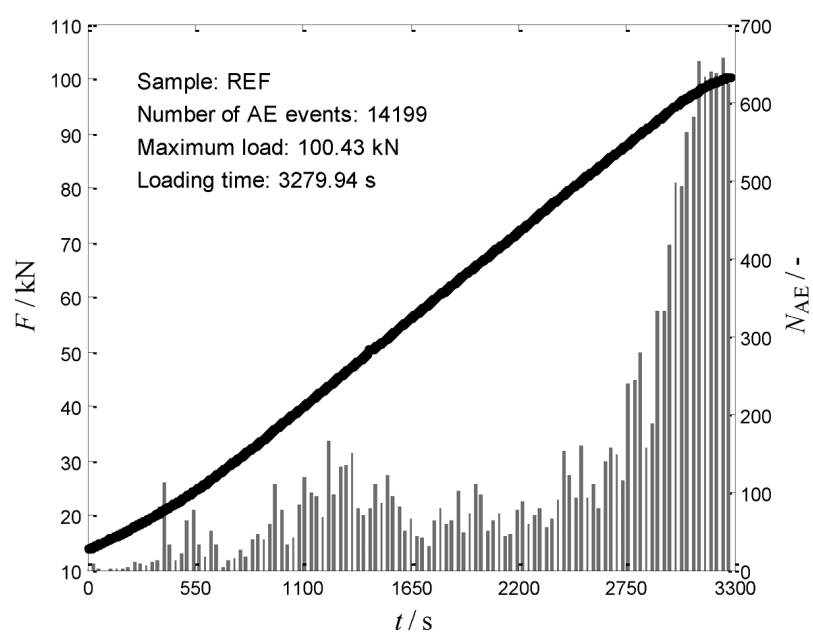

Figure 2: Applied mechanical load and the distribution of the fracture events (triggered by the AE signals) in time, sample REF

Slika 2: Uporabljena mehanska obremenitev in časovna razporeditev pojavov loma (sproženega z AE signali), vzorec REF

\section{RESULTS AND DISCUSSION}

Six groups of lightweight concrete samples with various types and amounts of fibers were prepared for a two-channel (EME and AE) measurement on our experimental set-up. The measured specimens were concrete blocks of overall dimensions $100 \mathrm{~mm} \times 100 \mathrm{~mm} \times 100$ $\mathrm{mm}$. These blocks from each of the prepared groups were measured for defined loading conditions (linearly increasing the uniaxial compression up to a load of 110 $\mathrm{kN}$ with a rate of $27 \mathrm{~N} / \mathrm{s}$.). The steel rods with a square cross-section of $8 \mathrm{~mm} \times 8 \mathrm{~mm}$ were inserted between the specimens and the hydraulic press jaws.

Figure 2 shows an example of the REF specimens' loading conditions, the curve of the applied mechanical load and the histogram describing the distribution of the fracture events (triggered by the AE signals) with time. Each bar in this chart describes the number of AE events during a time interval of $30 \mathrm{~s}$. The number of fracture events in individual time intervals is almost constant below the applied load of approximately $85 \mathrm{kN}$. The number of fracture events exponentially increases above this load level. The peak in the maximum value corresponds to the start of the whole sample destruction. In Figure 2 we can also see that the force versus time is linear only for the range of $20 \mathrm{kN}$ to $95 \mathrm{kN}$. This is due to the hydraulic press.

Figures 3 and $\mathbf{4}$ show examples of the measured signals that contain only separated EME and AE events.

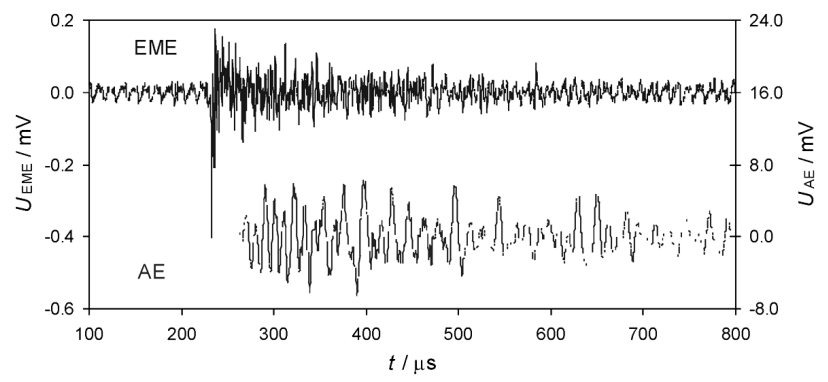

Figure 3: Separated EME and AE events, mechanical load $64.33 \mathrm{kN}$, sample MIX2

Slika 3: Ločeni EME in AE dogodki, mehanska obremenitev $64,33 \mathrm{kN}$, vzorec MIX2

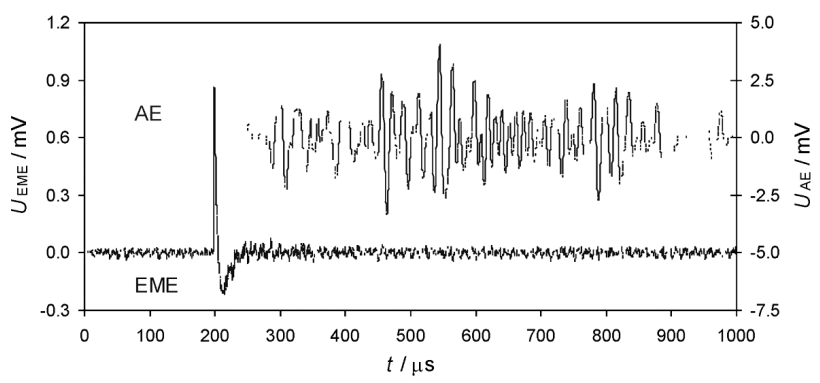

Figure 4: Separated EME and AE events, mechanical load $107.06 \mathrm{kN}$, sample MIX2

Slika 4: Ločeni EME in AE dogodki, mehanska obremenitev $107,06 \mathrm{kN}$, vzorec MIX2 


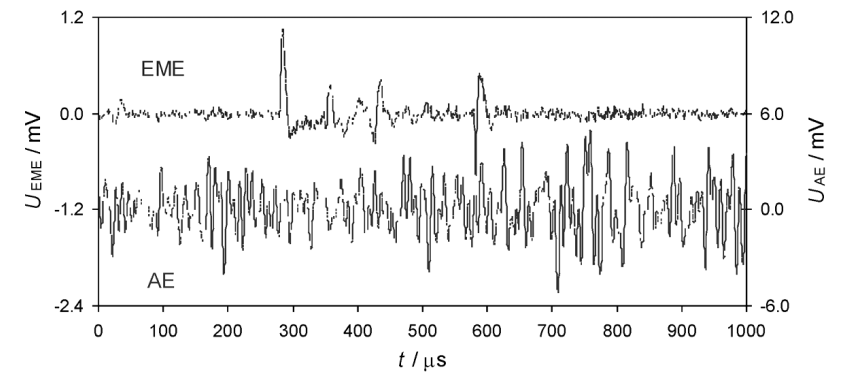

Figure 5: Continuous EME and AE events, mechanical load $76.23 \mathrm{kN}$, sample EN38

Slika 5: Neprekinjeni EME in AE dogodki, mehanska obremenitev $76,23 \mathrm{kN}$, vzorec EN38

The time delay between both signals is caused by the different propagation velocities of the acoustic and electromagnetic signals in the sample under examination. The AE signal time latency to the EME signal arrival provides information about the distance of the crack from the AE sensor. In the case of the AE signal multi-

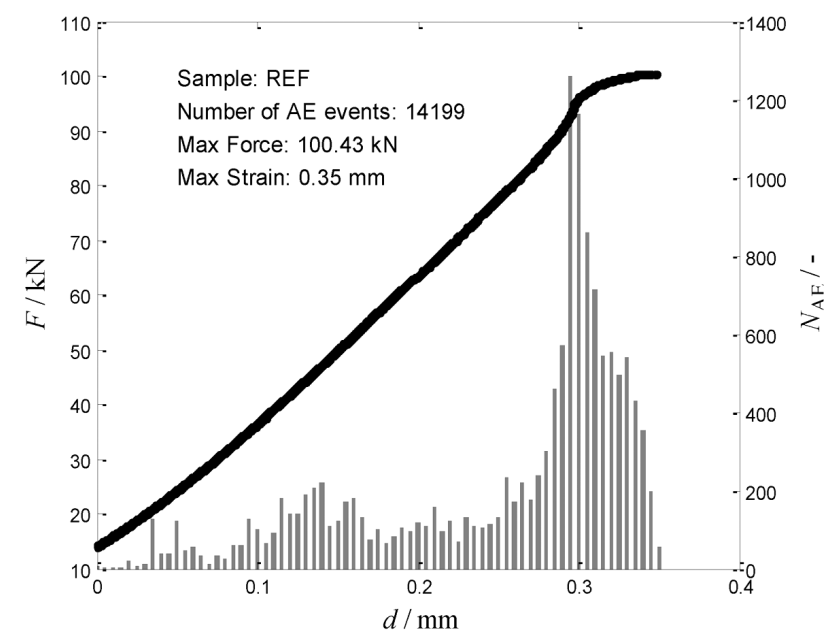

Figure 6: Sample REF - AE intensity

Slika 6: Vzorec REF - intenzivnost AE

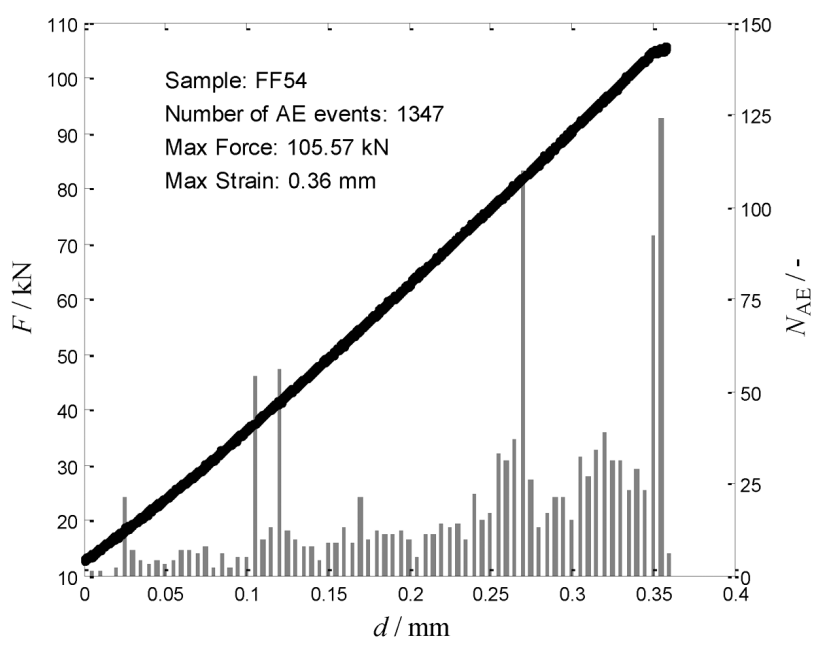

Figure 7: Sample FF54 - AE intensity

Slika 7: Vzorec FF54 - intenzivnost AE channel measurement, we can get useful information about the crack's position in the stressed material. ${ }^{12,13}$ The formation of the continuous EME and AE signals (Figure 5) occurs just before the total destruction of the whole sample. In the case of the EN38 sample, the maximum load (before the sample destruction) was approximately $82 \mathrm{kN}$.

The curves of the applied force versus sample deflection (contraction) for the individual measured concrete samples are in Figures 6 to 11. The histograms in these figures illustrate the distribution of the $\mathrm{AE}$ fracture events depending on the increasing sample contraction. The numbers of $\mathrm{AE}$ and EME events, the maximum force and the maximum strain of the measured samples are shown in Table 3. The cumulative numbers of detected AE events for a defined applied force are in Figure 12. Figure 13 shows the dependence of the cumulative number of $\mathrm{AE}$ events on the total dosage of polypropylene fibers in $1 \mathrm{~m}^{3}$ of lightweight concrete mixture for a defined mechanical load.

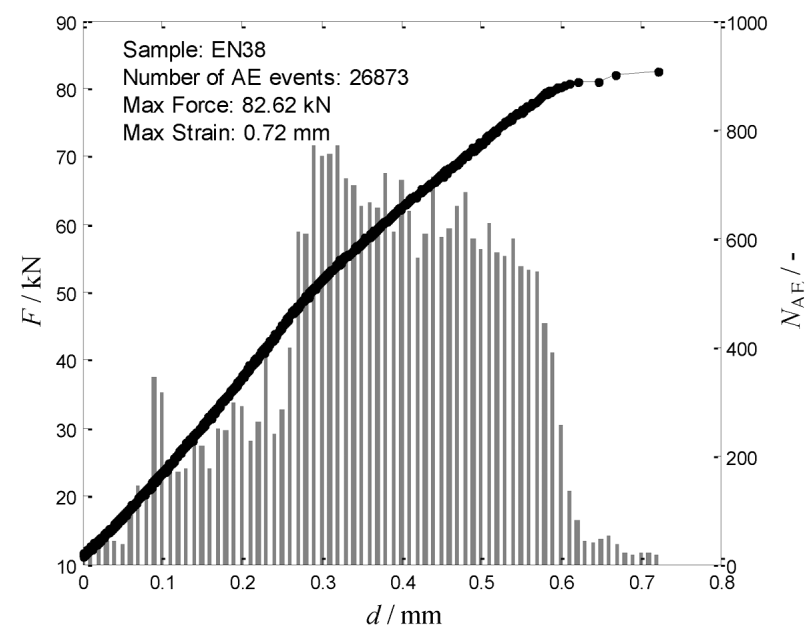

Figure 8: Sample EN38 - AE intensity

Slika 8: Vzorec EN38 - intenzivnost AE

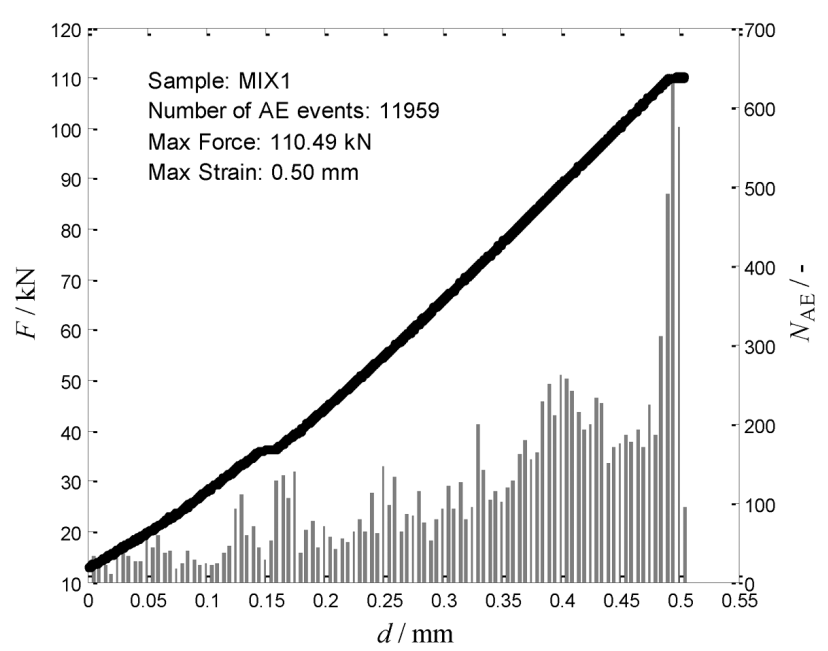

Figure 9: Sample MIX1 - AE intensity

Slika 9: Vzorec MIX1 - intenzivnost AE 


\section{R. ŠTOUDEK et al.: ACOUSTIC AND ELECTROMAGNETIC EMISSION OF LIGHTWEIGHT CONCRETE ...}

Table 3: Numbers of AE and EME events, maximum force and maximum strain of measured samples

Tabela 3: Števila dogodkov AE in EME, maksimalna sila in maksimalna napetost izmerjenih vzorcev

\begin{tabular}{|c|c|c|c|c|c|c|}
\hline $\begin{array}{c}\text { Designation of } \\
\text { the mixture }\end{array}$ & REF & FF54 & EN38 & MIX1 & MIX2 & MIX3 \\
\hline $\begin{array}{c}\text { Number of AE } \\
\text { events }\end{array}$ & 14199 & 1347 & 26873 & 11959 & 7123 & 16644 \\
\hline $\begin{array}{c}\text { Number of EME } \\
\text { events }\end{array}$ & 25 & 4 & 166 & 13 & 113 & 96 \\
\hline $\begin{array}{c}\text { Maximum force } \\
(\mathrm{kN})\end{array}$ & 100.43 & 105.57 & 82.62 & 110.49 & 107.90 & 108.09 \\
\hline $\begin{array}{c}\text { Maximum strain } \\
(\mathrm{mm})\end{array}$ & 0.348 & 0.358 & 0.723 & 0.504 & 0.475 & 0.437 \\
\hline
\end{tabular}

\section{CONCLUSIONS}

For the EN38 sample it is evident that the intensity of the detected AE signals increases from the beginning of the mechanical loading (Figure 6) and the cumulative number of AE events for a defined load reaches signifi-

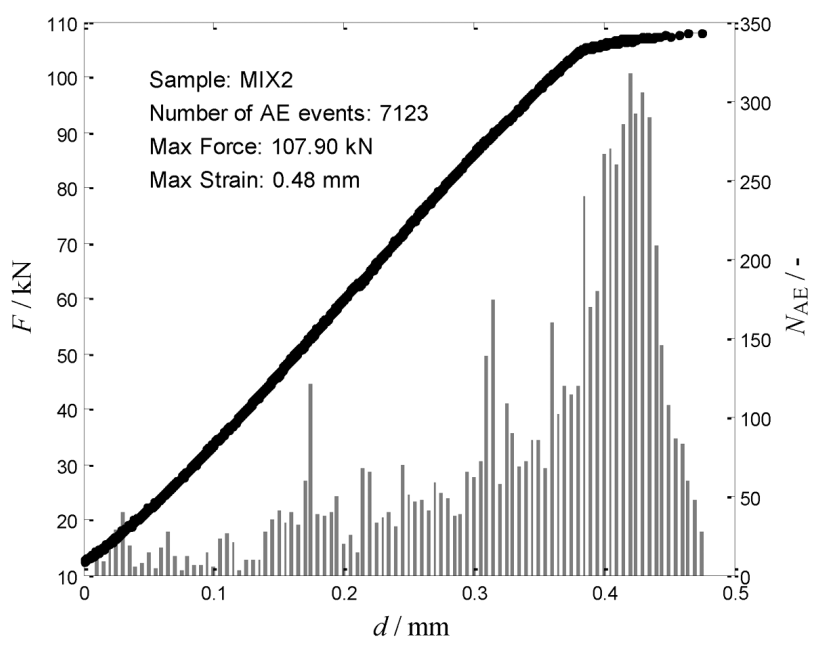

Figure 10: Sample MIX2 - AE intensity

Slika 10: Vzorec MIX 2 - intenzivnost AE

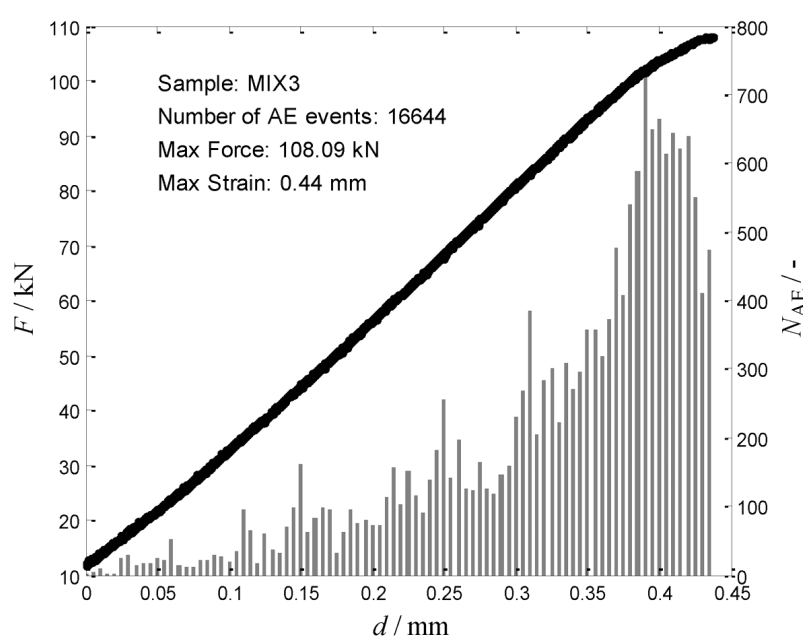

Figure 11: Sample MIX3 - AE intensity

Slika 11: Vzorec MIX3 - intenzivnost AE cantly higher values compared to the rest of the samples. This is only valid for a mechanical load of approximately $83 \mathrm{kN}$, during which the EN38 sample was destroyed (Figure 12). By contrast, for the sample FF54 we recorded the lowest value of AE events for every load. We can see in Figure 12 that the REF sample (without polypropylene fibers) is located between the FF54 and EN38 samples. The low strength and the high AE activity of sample EN38 is probably due to pulping fiber bundles and their re-clustering already during mixing. In the production of this sample we observed a noticeable increase in the volume of the mixture.

From the cumulative number of AE events (Figure 12) we can plot the dependence of the total number of $\mathrm{AE}$ events on the total dosage of polypropylene fibers for a defined mechanical load (Figure 13). In this figure we can see only the REF sample and the samples with mixtures of fibers. There is a clear minimum of AE activity

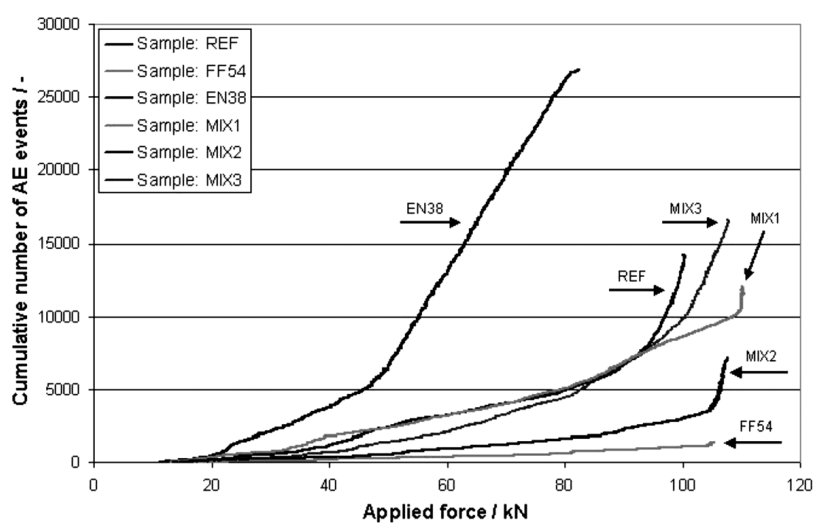

Figure 12: Cumulative numbers of detected $\mathrm{AE}$ events for a defined applied force

Slika 12: Kumulativno število zabeleženih dogodkov AE pri določeni uporabljeni sili

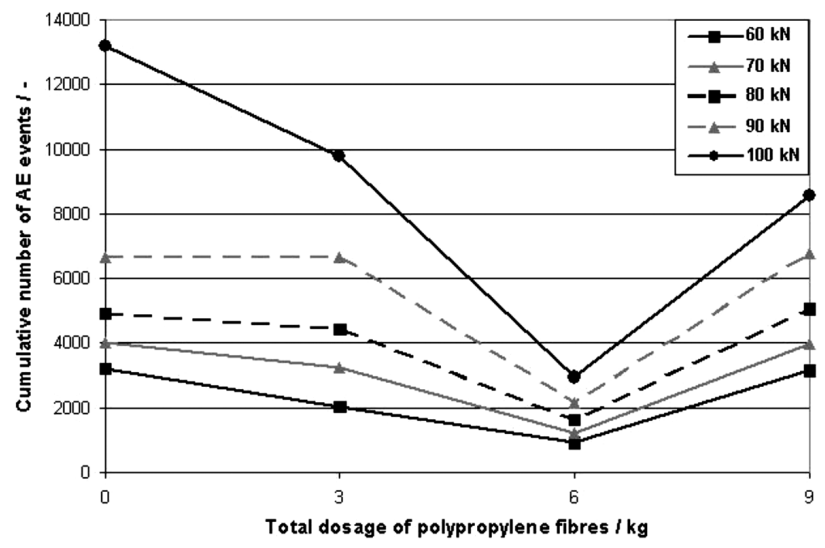

Figure 13: Dependence of the cumulative number of AE events on the total dosage of polypropylene fibers in $1 \mathrm{~m}^{3}$ of lightweight concrete mixture for a defined mechanical load (REF $-0 \mathrm{~kg}$, MIX3 $-3 \mathrm{~kg}$, MIX2 - $6 \mathrm{~kg}$, MIX1 - $9 \mathrm{~kg}$ )

Slika 13: Odvisnost kumulativnega števila dogodkov pri AE od celotnega odmerka polipropilenskih vlaken $\mathrm{v} 1 \mathrm{~m}^{3}$ mešanice lahkega betona pri določeni mehanski obremenitvi ( REF $-0 \mathrm{~kg}$, MIX3 - $3 \mathrm{~kg}$, MIX2 - $6 \mathrm{~kg}$, MIX1 - $9 \mathrm{~kg}$ ) 


\section{R. ŠTOUDEK et al.: ACOUSTIC AND ELECTROMAGNETIC EMISSION OF LIGHTWEIGHT CONCRETE ...}

for the sample MIX2 (a total of $6 \mathrm{~kg}$ of polypropylene fibers in $1 \mathrm{~m}^{3}$ of concrete mixture). A smaller dosage of fibers does not have such a big impact - sample MIX3 (total $3 \mathrm{~kg}$ ) and a larger dosage seems to be reflected again in the clustering of polypropylene fibers - sample MIX1 (total $9 \mathrm{~kg}$ ).

In the case of electromagnetic emission the largest total detected EME event was again for the EN38 sample (Table 3). But the number of these events in all the samples is too small for any conclusions to be drawn.

From the obtained results it can be concluded that the generated cracks' intensity is significantly affected by the total dosage of polypropylene fibers and by their length (and type). More detailed studies would require additional measurements on a larger number of lightweight concrete samples with defined compositions.

\section{Acknowledgments}

This paper has been written as part of the project No. LO1408 "AdMaS UP - Advanced Materials, Structures and Technologies", supported by Ministry of Education, Youth and Sports under the "National Sustainability Programme I" and under the project of Czech Science Foundation project GA13-18870S and specific research program at Brno University of Technology, project No. FAST-S-13-2149.

\section{REFERENCES}

${ }^{1}$ B. Kucharczykova, Z. Kersner, O. Pospichal, P. Misak, T. Vymazal, Influence of freeze-thaw cycles on fracture parameters values of lightweight concrete, Procedia Engineering. 2 (2010) 1, 959-966, doi:10.1016/j.proeng.2010.03.104

${ }^{2}$ J. T. Dickinson, M. K. Park, E. E. Donaldson, L. C. Jensen, Fracto-emission accompanying adhesive failure, Journal of Vacuum Science \& Technology A Vacuum Surfaces and Films, 20 (1982) 3, 436-439, doi:10.1116/1.571327

${ }^{3}$ J.T. Dickinson, E.E. Donaldson, M.K. Park, The emission of electrons and positive ions from fracture of materials, Journal of Materials Science, 16 (1981) 10, 2897-2908, doi:10.1007/ BF00552976
${ }^{4}$ R. Macku, P. Koktavy, Analysis of fluctuation processes in forward-biased solar cells using noise spectroscopy, Physica Status Solidi, 207 (2010) 10, 2387-2394, doi:10.1002/pssa.201026206

${ }^{5}$ V. Hadjicontis, G.S. Tombras, D. Ninos, C. Mavromatou, Memory effects in EM emission during uniaxial deformation of dielectric Crystalline materials, Geoscience and Remote Sensing Letters IEEE, 2 (2005) 2, 118-120, doi:10.1109/LGRS.2004.842472

${ }^{6}$ Y. Mori, K. Sato, Y. Obata, K. Mogi: Acoustic emission and electric potential changes of rock samples under cyclic loading, Proc. of the International Acoustic Emission Symposium, Kamuela, Hawaii, 1998, S45-S52, ISSN: 0730-0050

${ }^{7}$ P. Koktavy, J. Pavelka, J. Sikula, Characterization of acoustic and electromagnetic emission sources, Measurement Science and Technology, 15 (2004) 5, 973-977, doi: 10.1088/0957-0233/15/5/028

${ }^{8}$ P. Koktavy, Experimental study of electromagnetic emission signals generated by crack generation in composite materials, Measurement Science and Technology, 20 (2009) 1, 1-8, doi:10.1088/09570233/20/1/015704

${ }^{9}$ P. Koktavy, T. Trcka, B. Koktavy: Noise diagnostics of advanced composite materials for structural applications, Proc. of the $21 \mathrm{st}$ International Conference on Noise and Fluctuations, Toronto, 2011, 88-91, doi:10.1109/ICNF.2011.5994391

${ }^{10}$ L. Topolar, L. Pazdera, V. Bilek, L. Dedeckova: Acoustic Emission Method Applied on Four Point Loading of Concrete Structures with and without Small Wires, Proc. of the 50th Annual Conference on Experimental Stress Analysis, Prague, 2012, 477-484, ISBN 978-80-01-05060-6

${ }^{11}$ T. Trcka, P. Koktavy, P. Tofel, Electromagnetic and Acoustic Emission Signals Real-Time Measurement, Processing and Data Evaluation, Key Engineering Materials, 465 (2011), 318-321, doi:10.4028/www.scientific.net/KEM.465.318

${ }^{12}$ P. Sedlak, Y. Hirose, S. Khan, M. Enoki, J. Sikula, New automatic localization technique of acoustic emission signals in thin metal plates, Ultrasonics, 49 (2009) 2, 254-262, doi:10.1016/j.ultras. 2008.09.005

${ }^{13}$ P. Sedlak, J. Sikula, T. Lokajicek, Y. Mori, Acoustic and electromagnetic emission as a tool for crack localization, Measurement Science and Technology, 19 (2008) 4, 1-7, doi:10.1088/09570233/19/4/045701

${ }^{14}$ L. Pazdera, L. Topolar, Application acoustic emission method during concrete frost resistance, Russian Journal of Nondestructive Testing, 50 (2014) 2, 127-132, doi:10.1134/S1061830914020065 